\title{
Mycosarcoma (Ustilaginaceae), a resurrected generic name for corn smut (Ustilago maydis) and its close relatives with hypertrophied, tubular sori
}

\author{
Alistair R. McTaggart ${ }^{1,2}$, Roger G. Shivas ${ }^{3}$, Teun Boekhout4 ${ }^{4,5}$, Franz Oberwinkler ${ }^{6}$, Kálmán Vánky ${ }^{7}$, Shaun R. Pennycook ${ }^{8}$, and \\ Dominik Begerow ${ }^{9}$
} \begin{abstract}
Institute (FABI), Private Bag X20, University of Pretoria, Pretoria, 0028, South Africa
2Plant Biosecurity Cooperative Research Centre, LPO Box 5012, Bruce 2617, Australia Australia

${ }^{4}$ CBS-KNAW Fungal Biodiversity (CBS-KNAW), Utrecht, The Netherlands

5 Institute of Biodiversity and Ecosystems Dynamics (IBED), University of Amsterdam, Amsterdam

${ }^{6}$ Eberhard-Karls Universität, Auf der Morgenstelle 5, D-72076 Tübingen, Germany

${ }^{7}$ Herbarium Ustilaginales Vánky (HUV), Gabriel-Biel-Str. 5, D-72076 Tübingen, Germany

${ }^{8}$ Landcare Research Manaaki Whenua, Private Bag 92170, Auckland 1142, New Zealand begerow@rub.de

Abstract: Ustilago is a polyphyletic genus of smut fungi found mainly on Poaceae. The development of a taxonomy that reflects phylogeny requires subdivision of Ustilago into smaller monophyletic genera. Several separate systematic analyses have determined that Macalpinomyces mackinlayi, M. tubiformis, Tolyposporella pachycarpa, Ustilago bouriquetii and U. maydis, occupy a unique phylogenetic position within the Ustilaginaceae. A previously introduced monotypic generic name typified by $U$. maydis, Mycosarcoma, is available to accommodate these species, which resolves one component of polyphyly for Ustilago s. lat. in Ustilaginaceae. An emended description of Mycosarcoma is provided to reflect the morphological synapomorphies of this monophyletic group. A specimen of Ustilago maydis that has had its genome sequenced is designated as a neotype for this species. Taxonomic stability will further be provided by a forthcoming proposal to conserve the name Uredo maydis over Lycoperdon zeae, which has priority by date, in order to preserve the well-known epithet maydis.
\end{abstract}

${ }^{1}$ Department of Microbiology and Plant Pathology, Tree Protection Co-operative Programme (TPCP), Forestry and Agricultural Biotechnology

${ }^{3}$ Plant Pathology Herbarium, Biosecurity Queensland, Department of Agriculture and Fisheries, GPO Box 267, Brisbane 4001, Queensland,

${ }^{9}$ Ruhr-Universität Bochum, Geobotanik, ND 03/174, Universitätsstr. 150, 44801 Bochum, Germany; corresponding author e-mail: dominik.

Key words: model organism name change Pseudozyma synapomorphy taxonomy Ustilaginomycotina

Article info: Submitted: 16 November 2016; Accepted: 18 November 2016; Published: 29 November 2016.

\section{INTRODUCTION}

There are 14 genera of smut fungi recognized in Ustilaginaceae (Ustilaginomycetes) on grasses: Anomalomyces, Anthracocystis, Franzpetrakia, Langdonia, Macalpinomyces, Moesziomyces, Sporisorium, Stollia, Tranzscheliella, Triodiomyces, Tubisorus, Ustilago, Yenia, and Yunchangia. These genera are distinguished by morphology of the sori and spores, as well as host range and phylogenetic relationships supported by molecular data (Begerow et al. 2014). Species of Ustilago destroy leaves and inflorescences of hosts in Poaceae, mostly producing sori that rupture at maturity to expose blackish spore masses. Ustilago became a catch-all for many unrelated species of smut fungi, and is polyphyletic (McTaggart et al. 2012b, Begerow et al. 2014, Savchenko et al. 2014). Ustilago, in the strict sense, occurs mainly on hosts in the tribe Pooideae and lacks soral structures, specifically, a columella, spore balls and sterile cells (McTaggart et al. 2012a). Additionally, members of the asexual yeast genera Pseudozyma and Farysizyma are polyphyletic in different lineages of Ustilaginales (Begerow et al. 2000, 2014, Boekhout 1995, Inacio et al. 2008, Wang et al. 2015). Some of these asexual yeasts were described without awareness of their sexual morphs, which are known to be plant pathogenic or potentially plant pathogenic (Wang et al. 2015). A phylogenetic species concept that places species of yeast into resolved genera has commenced for yeasts in Anthracocystis and other taxa (Piątek et al. 2015, Wang et al. 2015).

The known genera of smut fungi reflect synapomorphies, whether found in cellular ultrastructure or gross morphological characters of the sorus (Begerow et al. 2014). These synapomorphies are supported by DNA sequence data (Begerow et al. 2014). Recent taxonomic changes for smut fungi reflect phylogenetic classification, for example

\section{○ 2016 International Mycological Association}

You are free to share - to copy, distribute and transmit the work, under the following conditions:

Attribution: $\quad$ You must attribute the work in the manner specified by the author or licensor (but not in any way that suggests that they endorse you or your use of the work).

Non-commercial: $\quad$ You may not use this work for commercial purposes.

No derivative works: You may not alter, transform, or build upon this work.

For any reuse or distribution, you must make clear to others the license terms of this work, which can be found at http://creativecommons.org/licenses/by-nc-nd/3.0/legalcode. Any of the above conditions can be waived if you get permission from the copyright holder. Nothing in this license impairs or restricts the author's moral rights. 


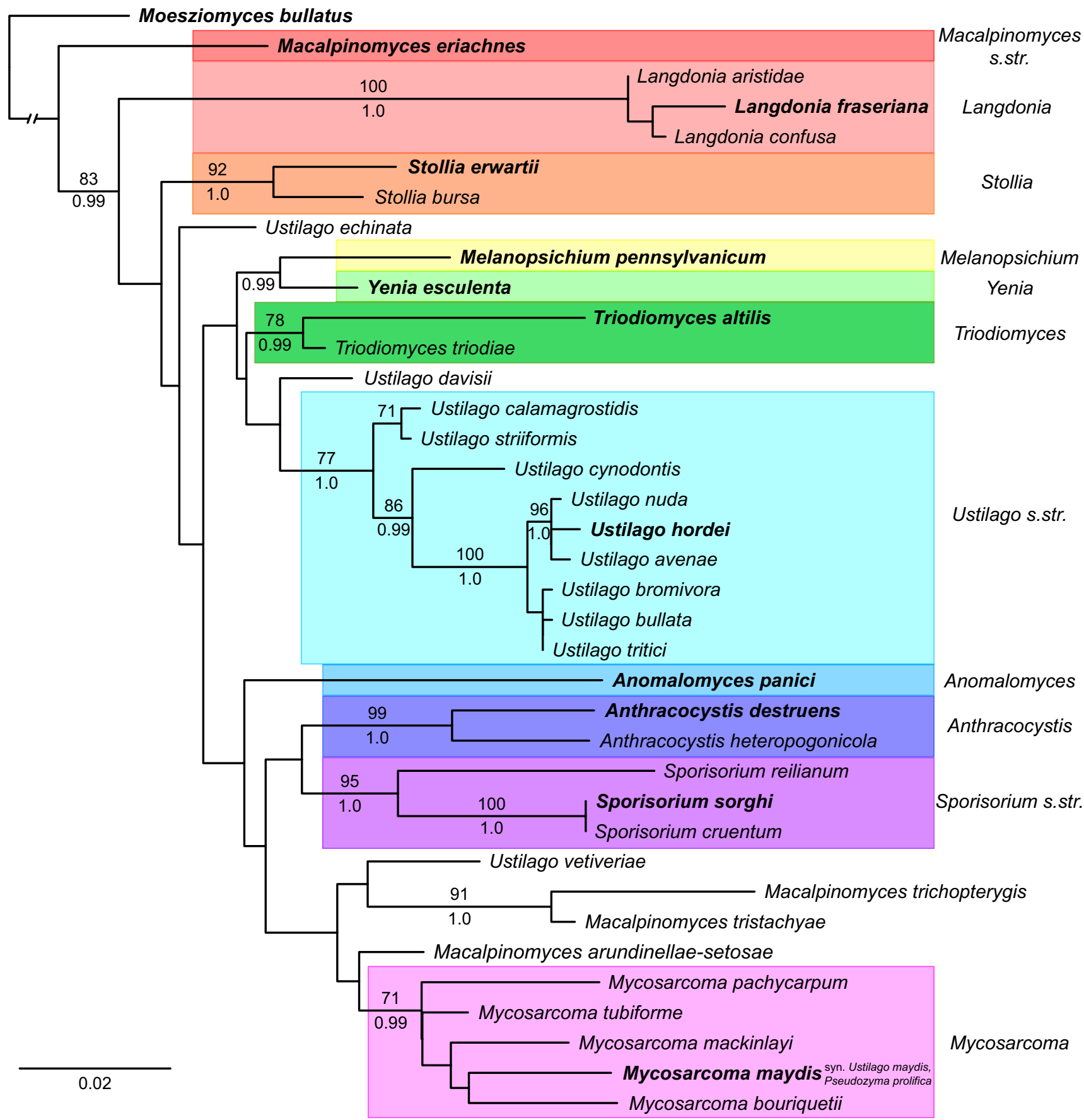

Fig. 1. Phylogram obtained from a maximum likelihood search in RAxML v8 (Stamatakis 2014) with a partitioned dataset of the internal transcribed spacer and large subunit regions of ribosomal DNA. Bootstrap values ( $\geq 70 \%)$ from 1000 replicates in a maximum likelihood search above nodes. Posterior probabilities ( $\geq 0.95)$ summarized from 18000 converged trees obtained from four runs each consisting of four chains in a Bayesian search with MrBayes (Ronquist \& Huelsenbeck 2003) below nodes. GTRGAMMA was the model of evolution for both phylogenetic criteria. Taxon name, host and GenBank numbers listed in Table 1. Type species of the genera included in the Ustilaginaceae are in bold font.

the separation of Microbotryales from Ustilaginomycotina (Begerow et al. 1997, 2014), and division of the UstilagoSporisorium-Macalpinomyces complex into smaller, welldefined genera (McTaggart et al. 2012c). In the latter example, smut fungi on grasses in the Ustilago-SporisoriumMacalpinomyces complex were divided into the genera Anthracocystis, Langdonia, Stollia, Triodiomyces and Tubisorus (Vánky \& Lutz 2011, McTaggart et al. 2012c).

Ustilago maydis, the cause of boil or blister smut of corn (Zea mays), forms localized, hypertrophied sori on the stems, leaves and inflorescences. It is an important model organism for the study of reproduction (Bakkeren et al. 2006), infection pathways (Muller et al. 2008), virulence and cellular signaling in fungi (Brefort et al. 2009). It was the first species of Ustilaginomycotina to have a publicly available genome (Kämper et al. 2006), which has since been used for comparative genomics between corn smut and other fungi (e.g. Xu et al. 2007). Molecular phylogenetic studies 
have shown that the mitosporic Pseudozyma prolifica is conspecific with $U$. maydis (Begerow et al. 2000, Boekhout 2011).

Comparative studies on the genomes of smut fungi have indicated that $U$. maydis is more closely related to other taxa than to species of Ustilago. For example, differences in the mating systems and methods of RNA silencing between $U$. maydis and $U$. hordei (the type species of Ustilago, notwithstanding a proposal by Thines (2016) to conserve Ustilago with $U$. maydis as the conserved type) indicated a relatively distant phylogenetic relationship (Bakkeren et al. 2006, Bakkeren et al. 2008, Laurie et al. 2008). Kellner et al. (2011) showed the mating type loci of Sporisorium reilianum, Ustanciosporium gigantosporum and related species had some degree of synteny to the corresponding genes of $U$. maydis. Future studies may determine whether more closely related species have higher synteny and whether genes involved in mating and self-recognition are conserved within genera.

Systematic studies showed that $U$. maydis was not closely related to species of Ustilago s. str., and was instead recovered as sister to species of Sporisorium and Anthracocystis (Piepenbring et al. 2002, Stoll et al. 2005, Vánky \& Lutz 2011, McTaggart et al. 2012a). In these studies, $U$. maydis was closely related to $U$. bouriquetii, a smut fungus that forms hypertrophied sori in the inflorescences of Stenotaphrum (Poaceae). McTaggart et al. (2012a) recovered $U$. maydis in a clade with Macalpinomyces mackinlayi, $M$. tubiformis, Tubisorus pachycarpus and $U$. bouriquetii, which all form hypertrophied sori in inflorescences of their hosts. McTaggart et al. (2012a) considered that localised, hostderived, hypertrophied sori were an apomorphy for this group (Fig. 2). Vánky \& Lutz (2011) introduced a new generic name, Tubisorus, typified by T. pachycarpus, which was recovered in a clade with $U$. maydis. Tubisorus was characterized by tubular sori filled with spores compacted in loose spore balls.

Mycosarcoma is the earliest available generic name for the clade containing $U$. maydis, which was described as the type species (Brefeld 1912). The characters that Brefeld
(1912) believed distinguished Mycosarcoma from Ustilago and Sporisorium were the: (1) incubation time in the host; (2) development of the sorus at the site of penetration in the host plant; (3) the development of aerial conidia; and (4) the presence of a peridium.

The current systematic understanding of the genera in Ustilaginaceae on Poaceae is shown in (Fig. 1; Table 1). In the present study the circumscription of Mycosarcoma is emended and the name resurrected to reflect contemporary knowledge of the synapomorphies within Ustilaginaceae. A taxonomic system based strictly on morphological synapomorphies is not possible for dimorphic plant pathogenic fungi like $U$. maydis, which have both asexual non-pathogenic yeast stages and sexual pathogenic teliospore stages in their life cycle.

Vánky (1990) discussed the nomenclatural history of $U$. maydis. The fungus was first described as Lycoperdon zeae by Beckmann, but this epithet could not be combined in Ustilago as it was pre-occupied by the name $U$. zeae (Link) Unger 1836 based on a different type (Vánky 1990). The next validly published binomial was U. maydis (DC.) Corda 1842, possibly the most well-known and intensively studied smut fungus in the world. For this reason, we seek to conserve this widely used epithet.

\section{TAXONOMY}

The following taxonomic combinations are based on the recovered phylogenetic tree (Fig. 1) and the apomorphies discussed above. Emended parts of the description are in italic type.

\section{Mycosarcoma Bref., Unters. Gesammtgeb. Mykol. 15: 53 (1912).}

Description: Sori usually in some ovaries of an inflorescence, derived from hypertrophied host material, often tubular, splitting longitudinally to expose the spore mass, partitioning
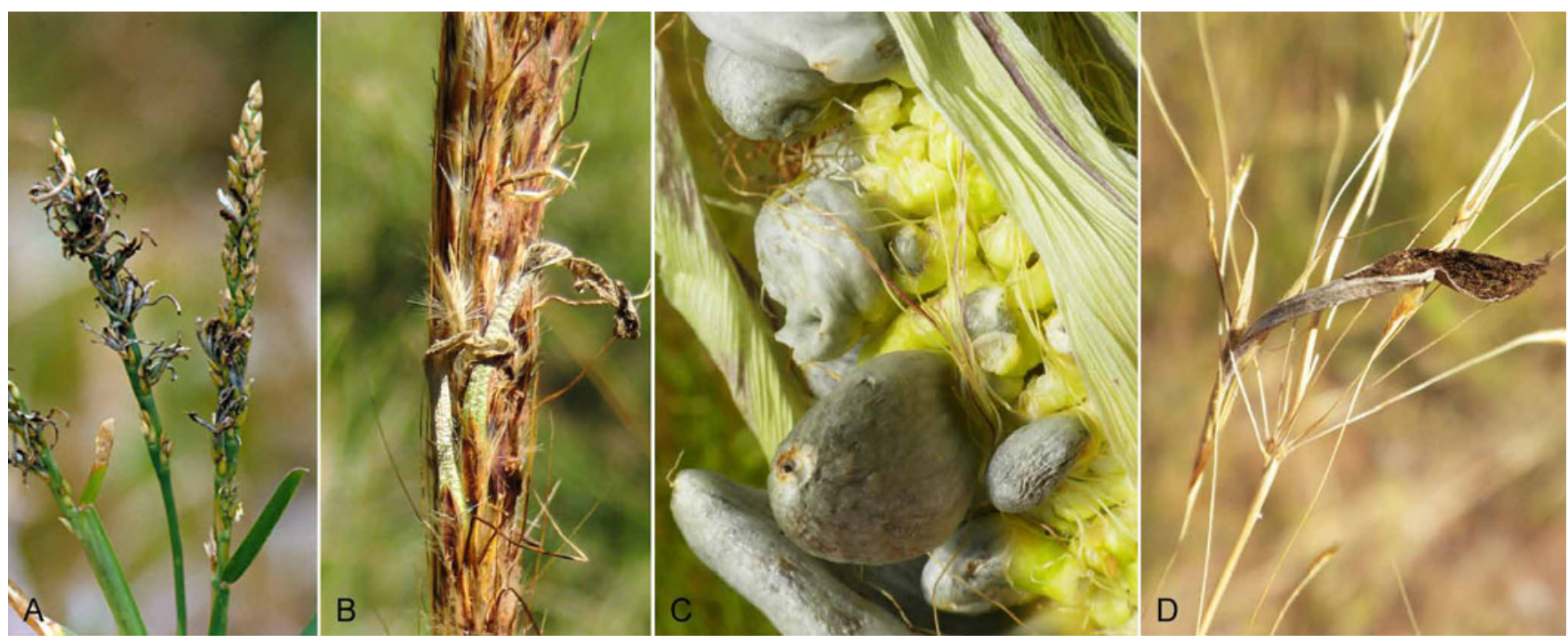

Fig. 2. A. Mycosarcoma bouriquetii on Stenotaphrum dimidatum (BRIP 26403). B. Mycosarcoma mackinlayi on Eulalia mackinlayi (BRIP 52549). C. Mycosarcoma maydis on Zea mays (BRIP 52746). D. Mycosarcoma tubiforme on Chrysopogon fallax (BRIP 57599). 
cells present or absent. Sori rarely in all organs: stems, leaves, inflorescences (male and female) and roots. Columellae absent. Spore balls derived from sporogenous hyphae absent. Germination of the Ustilago-type. Asexual; saprobic stages occur as yeasts on plant surfaces and other habitats.

Hosts: On grass hosts in subfamily Panicoideae (Poaceae).

Type species: Mycosarcoma maydis (DC.) Bref. 1912 (on Zea mays).

Mycosarcoma bouriquetii (Maubl. \& Roger) McTaggart, R.G. Shivas \& Begerow, comb. nov. MycoBank MB811941

Basionym: Ustilago bouriquetii Maubl. \& Roger, Bull. Soc. Mycol. France 50: 327 (1934).

Synonyms: Sphacelotheca mauritiana Zundel, Mycologia 36: 405 (1944); fide Vánky (1996:107).

Sorosporium stenotaphri Vienn.-Bourg., Ann. Inst. Natl. Agron. 47: 43 (1963); fide Vánky (1996:107).

Type: on Stenotaphrum dimidiatum, Madagascar

Mycosarcoma mackinlayi (McTaggart \& R.G. Shivas) McTaggart, R.G. Shivas \& Begerow, comb. nov. MycoBank MB811942

Basionym: Macalpinomyces mackinlayi McTaggart \& R.G. Shivas, Persoonia 23: 187 (2009).

Type: on Eulalia mackinlayi, Australia.

Mycosarcoma maydis (DC.) Bref., Unters. Gesammtgeb. Mykol. 15: 53 (1912).

Basionym: Uredo maydis DC., Fl. franç., edn 3, 6: 77 (1815). Synonyms:Ustilago maydis (DC.) Corda, Icon. Fung. 5: 3 (1842): type: USA: Minnesota: near St Paul, on Zea mays in a corn field, isolated from a germinating teliospore [collected by J.J. Christensen], P. Schreier, R. Kahmann, S. Leong \& R. Holiday (DSM 14603 - neotype designated here, MBT374099).

Lycoperdon zeae Beckm., Hannover. Mag. 6: 1330 (1768).

Uredo segetum [var.] mays-zeae DC., Fl. franç., edn 3, 2 : 596 (1805).

Ustilago zeae-maydis G. Winter, Rabenh. Krypt.-FI. 1(1): 97 (1881); as „U. Zeae Mays“.

Ustilago mays-zeae (DC.) Magnus, Verh. Bot. Ver. Prov. Brandenburg 37: 72 (1896) [,1895“].

Uredo zeae Schwein., Schr. Naturf. Ges. Leipzig 1: 71 (1822).

Caeoma zeae Link, Linné's Sp. Plant., 4 edn, 6(2): 2 (1825).

Ustilago zeae (Link) Unger, Ueber Einfluß Bodens: 211 (1836).

Ustilago euchlaenae Archang., Erb. Crittog. Ital., ser. 2, no. 1152 (1882).

Pseudozyma prolifica Bandoni, Bot. J. Linn. Soc. 91:38 (1985).

Notes: We are proposing elsewhere to the Nomenclature Committee for Fungi (NCF) that the name Uredo maydis should be conserved over Lycoperdon zeae in order to to preserve the well-known epithet "maydis", which has been used for this species for over two centuries, but does not have priority over "zeae" if combined into Mycosarcoma.

Neither Beckmann (1768) nor de Candolle (1815) designated specimens or illustrations that might serve as the nomenclatural types when Lycoperdon zeae and Uredo maydis were described. Nor were we able to locate specimens in German and French herbaria that pre-dated the descriptions by Beckmann (1768) or de Candolle (1815) that might have been studied by them. As there are no specimens or illustrations associated with the name $U$. maydis that might serve as a lectotype, we consequently designate a sequenced neotype for Ustilago maydis here. The neotype was chosen on the basis that it represented a typical strain of corn smut with a published genome sequenced by the Broad Institute (Kämper et al. 2006). Further, populations of corn smut in Europe have been found to be monophyletic (Begerow, unpubl.).

Mycosarcoma pachycarpum (Syd.) McTaggart, R.G. Shivas \& Begerow, comb. nov.

MycoBank MB811943

Basionym: Sorosporium pachycarpum Syd., Ann. Mycol. 26: 431 (1928).

Synonyms: Tolyposporella pachycarpa (Syd.) L. Ling, Sydowia 3: 133 (1949).

Endosporisorium pachycarpum (Syd.) Vánky, Mycotaxon 56: 213 (1995).

Tubisorus pachycarpus (Syd.) Vánky \& M. Lutz, Mycol. Balcan. 8: 131 (2011).

Type: on Rottboellia ophiuroides, Philippines.

Mycosarcoma tubiforme (R.G. Shivas \& Vánky) McTaggart, R.G. Shivas \& Begerow, comb. nov. MycoBank MB811944

Basionym: Macalpinomyces tubiformis R.G. Shivas \& Vánky, Fung. Divers. 16: 152 (2004).

Type: on Chrysopogon fallax, Australia.

\section{DISCUSSION}

Mycosarcoma is resurrected here and the circumscription emended to accommodate a monophyletic group in Ustilaginaceae; this addresses one further component of polyphyly in Ustilago s. lat. This taxonomy is supported by several separate systematic analyses that have determined a unique phylogenetic position of $M$. maydis within the family (Piepenbring et al. 2002, Stoll et al. 2005, Vánky \& Lutz 2011, McTaggart et al. 2012a). We will submit a proposal to the Nomenclature Committee for Fungi for conservation of Uredo maydis over the name Lycoperdon zeae, which has priority at species rank, to avoid a disadvantageous nomenclatural change, as 'maydis' is an accepted and widely used epithet for corn smut in plant pathology and genetics. If this proposal is successful, the name M. maydis will become secure.

Future studies that include more taxa and additional phylogenetically informative molecular markers may reveal 
Table 1. Taxon names and GenBank numbers of isolates used in the phylogenetic analyses.

\begin{tabular}{|c|c|c|c|}
\hline \multirow[t]{2}{*}{ Taxon } & \multirow[t]{2}{*}{ Host } & \multicolumn{2}{|c|}{ GenBank details } \\
\hline & & ITS & LSU \\
\hline Anomalomyces panici & Panicum trachyrhachis & DQ459348 ${ }^{1}$ & DQ4593471 \\
\hline Anthracocystis destruens & Panicum miliaceum & AY344976 2 & AY747077² \\
\hline Anthracocystis heteropogonicola & Heteropogon contortus & HQ01310133 & HQ0131353 \\
\hline Langdonia aristidae & Aristida hygrometrica & HQ013096 3 & NA \\
\hline Langdonia confusa & Aristida queenslandica & HQ013095 3 & HQ013132 3 \\
\hline Langdonia fraseriana & Aristida nitidula & HQ0131003 & NA \\
\hline Macalpinomyces arundinellae-setosae & Arundinella nepalensis & HQ013086 3 & NA \\
\hline Macalpinomyces eriachnes & Eriachne aristidea & AY740037² & AY740090² \\
\hline Macalpinomyces trichopterygis & Trichopteryx dregeana & AY740039² & AY740092² \\
\hline Macalpinomyces tristachyae & Loudetiopsis chrysothrix & AY740164² & NA \\
\hline Melanopsichium pennsylvanicum & Polygonum glabrum & AY740040² & AY7400932 \\
\hline Moesziomyces bullatus & Paspalum distichum & AY7401532 & AY7401532 \\
\hline Mycosarcoma bouriquetii & Stenotaphrum dimidiatum & AY7401672 & NA \\
\hline Mycosarcoma mackinlayi & Eulalia mackinlayi & GU0148174 & HQ0131313 \\
\hline Mycosarcoma maydis & Zea mays & AY345004 & AF453938 \\
\hline Mycosarcoma pachycarpum & Mnesithea rottboellioides & JN871718 & JN871717 \\
\hline Mycosarcoma tubiforme & Chrysopogon fallax & HQ013088 ${ }^{3}$ & NA \\
\hline Sporisorium cruentum & Sorghum halepense & AY344974² & AF4539396 \\
\hline Sporisorium reilianum & Zea mays & FJ1673578 & DQ8322289 \\
\hline Sporisorium sorghi & Sorghum bicolor & AF038828 10 & AF009872 $2^{11}$ \\
\hline Stollia bursa & Themeda quadrivalvis & AY740154² & NA \\
\hline Stollia ewartii & Sarga timorensis & HQ0130873 & HQ013127 3 \\
\hline Triodiomyces altilis & Triodia pungens & AY740166² & HQ013136 3 \\
\hline Triodiomyces triodiae & Triodia microstachya & AY740074² & AY740126² \\
\hline Ustilago avenae & Avena barbata & AY3449975 & AF4539336 \\
\hline Ustilago bromivora & Bromus catharticus & AY740064² & AY740118² \\
\hline Ustilago bullata & Bromus diandrus & AY3449985 & AF453935 \\
\hline Ustilago calamagrostidis & Calamagrostis epigeios & AY740065² & AY740119² \\
\hline Ustilago cynodontis & Cynodon dactylon & AY $345000^{5}$ & AF00988111 \\
\hline Ustilago davisii & Glyceria multiflora & AY740169² & NA \\
\hline Ustilago echinata & Phalaris arundinacea & AY $345001^{5}$ & AY740144² \\
\hline Ustilago hordei & Hordeum vulgare & AY $345003^{5}$ & AF4539436 \\
\hline Ustilago nuda & Hordeum leporinum & AY740069² & JN367334 $4^{13}$ \\
\hline Ustilago striiformis & Alopecurus pratensis & AY740172² & DQ875375 12 \\
\hline Ustilago tritici & Triticum aestivum & AF135424 ${ }^{14}$ & NA \\
\hline Ustilago vetiveriae & Vetiveria zizanioides & AY3450115 & AY740149² \\
\hline Yenia esculenta & Zizania latifolia & AY $345002^{5}$ & AF4539376 \\
\hline
\end{tabular}

${ }^{1}$ Vánky et al. (2006); ${ }^{2}$ Stoll et al. (2005); ${ }^{3}$ McTaggart et al. (2012a); ${ }^{4}$ McTaggart \& Shivas (2009); ${ }^{5}$ Stoll et al. (2003); ${ }^{6}$ Piepenbring et al. (2002); ${ }^{7}$ Vánky \& Lutz (2011); ${ }^{8}$ Zhang \& Gao (unpubl.); ${ }^{9}$ Matheny et al. (2006); ${ }^{10}$ Roux et al. (1998); ${ }^{11}$ Begerow et al. (1997); ${ }^{12}$ Begerow et al. (2006); ${ }^{13}$ Kellner et al. (2011); and ${ }^{14}$ Bakkeren et al. (2000).

that other species also belong to Mycosarcoma. In the present study, Macalpinomyces arundinellae-setosae and $U$. vetiveriae fit the morphological concept of Mycosarcoma, but were not recovered in Mycosarcoma with strong support in the phylogenetic analyses. Detailed studies on the ontogeny of sori and teliospores might help to further clarify the limits of Mycosarcoma. For example, Macalpinomyces trichopterygis, $M$. tristachyae, and M. simplex, which were included in the phylogenetic analyses, cause systemic infections on grasses in the subfamily Arundinoideae. These three species also have tubular, host-derived sori, and have a phylogenetic affinity with Mycosarcoma as shown in previous studies (Stoll et al. 2005, Vánky \& Lutz 2011, McTaggart et al. 2012a).

Thines (2016) proposed that $U$. maydis should be conserved as the type species of Ustilago to cement the name of this well-studied smut fungus. This was on the grounds that $U$. hordei, the current type, does not supersede $U$. segetum, which was designated as lectotype of Ustilago 
by Clinton (1904). However, U. segetum was not described as a distinct taxon, but initially as a set of three varieties (Persoon 1797), and subsequently sanctioned as a set of five varieties (Persoon 1801), with $U$. hordei the alpha variety, "Uredo segetum a Uredo hordei". Most of these varieties were subsequently raised to species rank (Lagerheim 1889, Saccardo 1891), and Clinton (1906) revised the name of his typification to $U$. hordei (Clinton 1906). As the alpha or 'typical' variety, $U$. hordei represents the name of the type after the species names Ustilago/Reticularia segetum were declared nomina utique rejicienda. Furthermore, Ustilago hordei is a conserved name with a type specimen studied by Persoon.

If Ustilago hordei were not the type, Ustilago maydis would not be a suitable choice as a replacement, because it is not among the species described in the sanctioning work (Art 10.2), it is not congeneric with Ustilago as described by Persoon (1801), and it would require $\sim 200$ name changes for species of Ustilago that are not congeneric with $U$. maydis. The mycological community has previously accepted name changes for model fungi such as Microbotryum violaceum and Zymoseptoria tritici, and the adoption of Mycosarcoma maydis will provide stability for two genera of smut fungi.

Ustilago maydis was recombined in Mycosarcoma a century ago to distinguish it from other species of smut fungi, particularly species of Ustilago. We suggest the scientific community adopts the taxonomy proposed by Brefeld (1912) and summarized here, to ensure classification reflects evolution.

\section{ACKNOWLEDGEMENTS}

We acknowledge financial support from both the Australian Government's Plant Biosecurity Cooperative Research Centre (grant S120010) and the Deutsche Forschungsgemeinschaft (DFG). TB was supported by a grant from Qatar National Research Fund (NPRP 5-298-3-086), a member of Qatar Foundation. The statements herein are solely the responsibility of the authors.

\section{REFERENCES}

Bakkeren G, Kronstad JW, Levesque CA (2000) Comparison of AFLP fingerprints and ITS sequences as phylogenetic markers in Ustilaginomycetes. Mycologia 92: 510-521.

Bakkeren G, Jiang G, Warren RL, Butterfield Y, Shin H, et al. (2006) Mating factor linkage and genome evolution in basidiomycetous pathogens of cereals. Fungal Genetics and Biology 43: 655-666.

Bakkeren G, Kämper J, Schirawski J (2008) Sex in smut fungi: structure, function and evolution of mating-type complexes. Fungal Genetics and Biology 45: S15-S21.

Bandoni RJ (1985) On an undescribed pleomorphic hyphomycete from litter. Botanical Journal of the Linnean Society 91: 37-43.

Beckmann J (1768) Des Herrn Tillet Beobachtung einer Krankheit des türkischen weizens oder der mais. Hannoverisches Magazin 6: 1329-1339.

Begerow D, Bauer R, Oberwinkler F (1997) Phylogenetic studies on nuclear large subunit ribosomal DNA sequences of smut fungi and related taxa. Canadian Journal of Botany 75: 2045-2056.
Begerow D, Bauer R, Boekhout T (2000) Phylogenetic placements of ustilaginomycetous anamorphs as deduced from nuclear LSU rDNA sequences. Mycological Research 104: 53-60

Begerow D, Stoll M, Bauer R (2006) A phylogenetic hypothesis of Ustilaginomycotina based on multiple gene analyses and morphological data. Mycologia 98: 906-916.

Begerow D, Schafer AM, Kellner R, Yurkov A, Kemler M, et al. (2014) Ustilaginomycotina. In: The Mycota Vol. 7A. Systematics and Evolution (McLaughlin DJ, Spatafora JW.eds): 295-329. $2^{\text {nd }}$ edn. Berlin: Springer.

Boekhout T (1995) Pseudozyma emend. Boekhout, a genus for yeast-like anamorphs of Ustilaginales. Journal of General Applied Microbiology 41: 359-366.

Boekhout T (2011) Pseudozyma Bandoni emend. Boekhout (1985) and a comparison with the yeast state of Ustilago maydis (De Candolle) Corda (1842). In: The Yeasts (Kurtzman C, Fell JW, Boekhout T, eds) 3: 1857-1868. Amsterdam: Elsevier.

Brefeld O (1812) Untersuchungen aus dem Gesammtgebiete der Mykologie. Vol. 15. Die Brandpilze und die Brandkrankheiten. 5: 1-151. Münster: Commissions-Verlag v. H. Schöningh.

Brefort T, Doehlemann G, Mendoza-Mendoza A, Reissmann S, Djamei A, et al. (2009) Ustilago maydis as a Pathogen. Annual Review of Phytopathology 47: 423-445.

Clinton GP (1904) North American Ustilagineae. Proceedings of the Boston Society for Natural History 31: 329-529.

Clinton GP (1906) Order Ustilaginales. North American Flora 7: 1-82. Inacio J, Landell MF, Valente P, Wang S-H, Manson JS, et al. (2008) Farysizyma gen. nov., an anamorphic genus in the Ustilaginales to accommodate three novel epiphytic basidiomycetous yeast species from America, Europe and Asia. FEMS Yeast Research 8: 499-508.

Kämper J, Kahmann R, Bolker M, Ma LJ, Brefort T, et al. (2006) Insights from the genome of the biotrophic fungal plant pathogen Ustilago maydis. Nature 444: 97-101.

Kellner R, Vollmeister E, Feldbrügge M, Begerow D (2011) Interspecific sex in grass smuts and the genetic diversity of their pheromone-receptor system. PLoS Genetics 7: e1002436.

Lagerheim G (1889). Revision der im Exsiccat 'Kryptogamen Badens von Jack, Leiner und Stizenberger' enthaltenen Chytridiaceen, Peronosporeen, Ustilagineen und Uredineen. Mitteilungen des Badischen Botanischen Vereins 1889: 69-76.

Laurie J, Linning R, Bakkeren G (2008) Hallmarks of RNA silencing are found in the smut fungus Ustilago hordei but not in its close relative Ustilago maydis. Current Genetics 53: 49-58.

Matheny PB, Gossman JA, Zalar P, Kumar TKA, Hibbett DS (2006) Resolving the phylogenetic position of the Wallemiomycetes: an enigmatic major lineage of Basidiomycota. Canadian Journal of Botany 84: 1794-1805.

McTaggart AR, Shivas RG (2009) Macalpinomyces mackinlayi. Persoonia 23: 186-187.

McTaggart AR, Shivas RG, Geering ADW, Callaghan B, Vánky K, Scharaschkin T (2012a) Soral synapomorphies are significant for the systematics of the Ustilago-Sporisorium-Macalpinomyces complex (Ustilaginaceae). Persoonia 29: 63-77.

McTaggart AR, Shivas RG, Geering ADW, Vánky K, Scharaschkin T (2012b) A review of the Ustilago-Sporisorium-Macalpinomyces complex. Persoonia 29: 55-62.

McTaggart AR, Shivas RG, Geering ADW, Vánky K, Scharaschkin T (2012c) Taxonomic revision of Ustilago, Sporisorium and Macalpinomyces. Persoonia 29: 116-132. 
Muller O, Schreier PH, Uhrig JF (2008) Identification and characterization of secreted and pathogenesis-related proteins in Ustilago maydis. Molecular Genetics and Genomics 279: 27-39.

Persoon CH (1797) Tentamen dispositionis methodicae Fungorum. Leipzig: P.P. Wolf.

Persoon CH (1801) Synopsis Methodica Fungorum. Vol. 1. Göttingen: H. Dieterich.

Piątek M, Lutz M, Yorou N (2015) A molecular phylogenetic framework for Anthracocystis (Ustilaginales), including five new combinations (inter alia for the asexual Pseudozyma flocculosa), and description of Anthracocystis grodzinskae sp. nov. Mycological Progress 14: 1-15.

Piepenbring M, Stoll M, Oberwinkler F (2002) The generic position of Ustilago maydis, Ustilago scitaminea, and Ustilago esculenta (Ustilaginales). Mycological Progress 1: 71-80.

Ronquist F, Huelsenbeck JP (2003) MrBayes 3: Bayesian phylogenetic inference under mixed models. Bioinformatics 19: 1572-1574.

Roux C, Almaraz T, Durrieu G (1998) Phylogénie de champignons responsables des charbons des végétaux à partir de l'analyse des séquences ITS. Comptes Rendus de l'Académie des Sciences, sér. 3, Sciences de la Vie 321: 603-609.

Saccardo PA (1891) Sylloge Fungorum Vol. 9. Berlin: R. Friedländer \& Sohn.

Savchenko KG, Carris LM, Castlebury LA, Heluta VP, Wasser SP, Nevo E (2014) Stripe smuts of grasses: one lineage or high levels of polyphyly? Persoonia 33: 169-181.
Stamatakis A (2014) RAxML Version 8: A tool for phylogenetic analysis and post-analysis of large phylogenies. Bioinformatics 30: 1312-1313.

Stoll M, Begerow D, Oberwinkler F (2005) Molecular phylogeny of Ustilago, Sporisorium, and related taxa based on combined analyses of rDNA sequences. Mycological Research 109: 342356.

Thines M (2016) Proposal to conserve the name Ustilago (Basidiomycota) with a conserved type. Taxon 65: 1170-1171.

Vánky K (1990) Taxonomical studies on Ustilaginales. VI. Mycotaxon 38: 267-278.

Vánky K (1996) Taxonomical studies on Ustilaginales. XIV. Mycotaxon 59: 89-113.

Vánky K, Lutz M, Shivas RG (2006) Anomalomyces panici, new genus and species of Ustilaginomycetes from Australia. Mycologia Balcanica 3: 119-126.

Vánky K, Lutz M (2011) Tubisorus, a new genus of smut fungi (Ustilaginomycetes) for Sporisorium pachycarpum. Mycologia Balcanica 8: 129-135.

Wang QM, Begerow D, Groenewald M, Liu XZ, Theelen B, Bai FY, Boekhout $T$ (2015) Multigene phylogeny and taxonomic revision of yeasts and related fungi in the Ustilaginomycotina. Studies in Mycology 81: 55-83.

Xu J, Saunders CW, Hu P, Grant RA, Boekhout T, et al. (2007) Dandruff-associated Malassezia genomes reveal convergent and divergent virulence traits shared with plant and human fungal pathogens. Proceedings of the National Academy of Sciences, USA 104: 18730-5. 